\title{
Czy tłumacz może pozwolić sobie na czułość? Spieszczenia a ekwiwalencja emocjonalna w przekładzie literackim
}

Kultura, rozumiana jako „wszelkie właściwe człowiekowi wyuczone i społecznie usankcjonowane sposoby działań i zachowań, a także wytwory tych działań" ", to również określona gramatyka uczuć, zespół reguł rządzących sposobami ich okazywania i wyrażania. Tylko z obowiązku powtórzę rzecz powszechnie znaną, że o ile w niektórych kulturach emocjonalność jest skrywana i tonowana, o tyle inne pozwalają jej okazywać się niemal bez ograniczeń. Te różne, czasem skrajne sposoby manifestowania uczuć, determinowane przez kulturę, a nie przez cechy osobowościowe jednostki, znajdują odzwierciedlenie w zróżnicowaniu struktur i mechanizmów językowych służących ekspresji stosunku emocjonalnego. Język polski na przykład pozwala rozlać się czułości szeroką falą na wszystkie poziomy języka i naznaczyć nią prawie każde słowo dzięki bogatemu systemowi zdrobnień i spieszczeń. Język angielski z kolei, pozbawiony takiego systemu, woli uczuciowość sugerowaną, raczej intonacyjną i brzmieniową niż morfologiczną bądź leksykalną.

Rodzi się więc pytanie, czy w sytuacji takiej asymetryczności kultur i języków możemy sensownie mówić o swego rodzaju ekwiwalencji uczuciowej w przekładzie. Problem jest rozległy. Tu skupię się na kłopotach związanych z oddaniem w thumaczeniu jednego z językowych sposobów wyrażania stosunku emocjonalnego, jakim są w polszczyźnie spieszczenia. Zajmę się także zasadnością wprowadzania spieszczeń do polskich przekładów tekstów, w których oryginale one nie występują. W odróżnieniu od zdrobnienia - będącego, jak pisze Jerzy Bartmiński, kategorią intelektualną, semantyczno-gramatyczną, której treścią jest

I Kultura [hasło], w: Maby stownik antropologiczny, red. T. Bielicki, Warszawa 1976, s. 229. 
informacja o małości danego przedmiotu - spieszczenie, czyli hipokoristikon, to kategoria emocjonalna, polegająca na komunikowaniu pieszczotliwego stosunku osoby mówiącej do przedmiotu $^{2}$. W polszczyźnie zdrobnienia i spieszczenia najczęściej mają identyczną postać, a ich funkcji tak prosto oddzielić nie można, dlatego Bartmiński wskazuje na formację deminutywno-hipokorystyczną3.

Nie aspirując do całościowego ujęcia zagadnienia, proponuję spojrzeć na kilka wybranych pod tym kątem tekstów literackich w przekładzie z polskiego na angielski i z angielskiego na polski, w których spieszczenia pojawiają się w wyraźnym zagęszczeniu.

Zacznę od Trenów Jana Kochanowskiego. Utwór ten, reprezentujący lirykę związaną ze śmiercią dziecka, w wielu swoich odsłonach z tym dzieckiem rozmawia. Małoletnia adresatka trenów determinuje rejestr, w którym toczy się wyimaginowana rozmowa obolałego ojca i zmarłej córki. Jaki to język? Nie bez powodu pytam o „język”, bo polszczyzna ma przecież osobną gramatykę, obowiązującą w sytuacji, gdy dorosły zwraca się do dziecka. I nie chodzi mi tu o zrozumiałe uproszczenie języka, tak składniowe, jak leksykalne, ale o coś bardziej systematycznego, na przykład użycie formy pierwszej osoby w funkcji drugiej osoby („no i co ja zrobiłem, rozlałem mleko, rozlałem?”). Mogą to być także, co mnie tu bardziej interesuje, zdrobnienia i spieszczenia, zarówno $\mathrm{w}$ funkcji informacyjnej, jak i emocjonalnej, których nasilenie $\mathrm{w}$ mowie do dziecka jest jej wyróżnikiem, cechą typową. Z takim językiem spotkamy się właśnie w Trenach.

Tren VII zaczyna się od wezwania skierowanego do przedmiotów związanych $\mathrm{z}$ córką, która tym samym przywołana jest początkowo w trzeciej osobie, „nieszczęsne ochędóstwo, żałosne ubiory/ Mojej najmilszej cory". W połowie wiersza jednak pełen żalu ojciec zmienia adresata i kieruje swoje słowa już bezpośrednio do córki: „moja dziewko droga”. Tren jest wyjątkowy w całym cyklu ze względu na zagęszczenie deminutywów w funkcji spieszczającej. Mamy tu bowiem (poza deminutywami „paski”, „dziewka” i „skrzynka”, które straciły swój deminutywny charakter): „członeczki”, „letniczek”, „uploteczki”, „giezłeczko”, „tkaneczkę" i „bryłeczkę".

Co ciekawe, są to wszystko deminutywa drugiego stopnia, w których sens podstawowy, opisowy czy informacyjny, schodzi na plan dalszy, ustępując miejsca emocjonalnemu nacechowaniu. Stąd też w literaturze przedmiotu stopień ten nazywa się demi-

${ }^{2}$ J. Bartmiński, Zdrobnienia ispieszczenia, w: idem, Ojezzyku folkloru, Wroclaw 1973, s. 138.

3 Ibidem, s. 139. 
nutywno-emocjonalnym, w odróżnieniu od stopnia pierwszego, deminutywnego. W przypadku „bryłeczki” stopniem podstawowym, neutralnym, jest „bryła”, deminutyw pierwszego stopnia to oczywiście „bryłka”, od niego zaś w procesie narastania zdrobnień zostaje utworzony deminutyw drugiego stopnia, z sensem emocjonalnym: „bryłeczka”. Podobnie jest z pozostałymi zdrobnieniami tego trenu. Deminutywa drugiego stopnia mają nieodmiennie charakter spieszczeń.

Co ważne, tak konsekwentny wybór leksykalny - to znaczy postawienie na liczne deminutywa, wszystkie drugiego stopnia, z końcówką fleksyjną - eczka - ma także, na co zwracają uwagę badacze, znaczenie rymotwórcze i pełni funkcję regulatora rytmu ${ }^{4}$. Zdrobnienia, niejako wskutek naturalnej skłonności, występują w dużych grupach, co sprzyja ich wykorzystywaniu do tworzenia rymu. Tak dzieje się w pieśniach ludowych, a w nieco mniejszym stopniu - także w Trenie VII.

Polszczyzna jest w zdrobnienia wyjątkowo bogata, tymczasem język angielski, jak pisał o tym wyczerpująco choćby Otto Jespersen, jest tego typu konstrukcji praktycznie pozbawiony. Jespersen pisze wprost o braku deminutywów jako właściwości charakterystycznej dla angielszczyzny5. W angielskim istnieją wprawdzie zdrobnienia i cząstki zdrabniające. Jeden $\mathrm{z}$ badaczy naliczył tych cząstek nawet pięćdziesiąt, a więc zdecydowanie więcej niż w polszczyźnie ${ }^{6}$. Ich zastosowanie jednak jest bardzo ograniczone, występowanie - często akcydentalne i nie są one słowotwórczo produktywne. Wyrazów zdrobniałych w angielszczyźnie znajdziemy zaledwie kilkadziesiąt, choć cząstek deminutywnych mamy pół setki. W polszczyźnie sytuacja wydaje się odwrotna: przyrostków jest dużo mniej, ale mogą się one łączyć z każdym rzeczownikiem i z wieloma przymiotnikami czy przysłówkami, pozwalając na słowotwórczą inwencję. Polszczyzna pozwala każde pojęcie wyrazić w postaci zdrobniałej i spieszczonej za pomocą deminutywum. To przejaw różnic między językami: polszczyzna jest językiem fleksyjnym, angielski - językiem analitycznym.

Jak możliwe jest więc oddanie tej szczególnej cechy języka Trenów w angielszczyźnie, jeśli system nie dysponuje ekwiwalentnymi środkami? Czy przekład na język, w którym nie występują spieszczenia, musi być przekładem pozbawionym ładunku

4 Ibidem, s. 170.

5 O. Jespersen, Growth and Structure of the English Language, Oxford 1948, s. 9.

${ }^{6}$ M. Nichol, 50 Diminutive Suffixes (and a Cute Little Prefix), www.dailywritingtips.com, dostęp: 4 maja 2014. 
emocjonalnego, jaki ze sobą spieszczenia niosą? Czy musimy $\mathrm{w}$ Trenach przełożonych na angielski zrezygnować $\mathrm{z}$ zawartej w nich czułości? Czy tłumacząc z polskiego na angielski, możemy oddać bogactwo sensów z pominięciem znaczeń emocjonalnych, tak w tekście Kochanowskiego konstytutywnych? Innymi słowy: czy możliwa jest ekwiwalencja emocjonalna?

Doświadczenie lekturowe podpowiada nam, że tak. Treny, które tłumaczone były na angielski kilkakrotnie, ostatnio, i niemal równocześnie, przez Michała Jacka Mikosia7, Adama Czerniawskiego $^{8}$ i Seamusa Heaneya we współpracy ze Stanisławem Barańczakiem ${ }^{9}$, nie są $\mathrm{w}$ angielskim przekładzie całkiem pozbawione swojej pierwotnej emocjonalności. Tłumacze próbują różnymi sposobami zachować te sensy, które konotuje zastosowanie przez poetę spieszczeń.

Przyrostki zdrabniające, mimo że liczne, mają w angielszczyźnie, jak powiedzieliśmy, bardzo ograniczone zastosowanie. Tłumacze stosują więc głównie zdrobnienia analityczne, opisowe, w których przed rzeczownikiem pojawia się w przekładzie przydawka small (mały). Warto zwrócić uwagę, że oprócz small $\mathrm{w}$ angielszczyźnie mamy przymiotnik little, który nie jest neutralny i poza informowaniem o wielkości przedmiotu konotuje wartościowanie pozytywne. Jeśli więc tłumacz uznaje, że deminutyw w polszczyźnie to nie tylko zdrobnienie, ale i spieszczenie, zamiast small winien użyć little. Jednak nadmierne zagęszczenie little byłoby stylistyczną skazą, więc jego występowanie musi być $\mathrm{z}$ natury rzeczy ograniczone. Tłumacze szukają innych określników, innych przydawek, które by konotowały emocjonalne zaangażowanie, choćby nie wprost. Oczywiście przychodzą na myśl słowa takie jak dear (drogi), lovely (cudowny), nice (mily), ale to - mówiąc wprost - nuda.

Są również inne, bardziej pomysłowe rozwiązania. Spośród trzech wymienionych thumaczy sięga po nie przede wszystkim, co chyba zrozumiałe, tłumacz, dla którego angielski jest językiem ojczystym - Heaney. Parę przykładów: słowo „letniczek”, które obaj tłumacze polscy przekładają na summer frock, a więc neutralnie, Heaney oddaje wyrażeniem, w którym pojawia się niespodziewanie inny przymiotnik, niebędący przekładem żadnego $\mathrm{z}$ przymiotników obecnych $\mathrm{w}$ oryginale. Zamiast summer frock, czyli dosłownie - letni fartuszek, Heaney pisze: flowered frock, czyli fartuszek w kwiatki. Podobnie dzieje się w przypadku słowa „ploteczki”: zamiast ribbons (wstążki)

\footnotetext{
7 J. Kochanowski, Treny. Laments, tłum. M.J. Mikoś, Warszawa 1995.

8 J. Kochanowski, Treny, thum. A. Czerniawski, Katowice 1996.

9 J. Kochanowski, Laments, tłum. S. Heaney, S. Barańczak, Londyn 1995.
} 
Heaney pisze smooth ribbons (gładkie wstążki). Czemu służy taki, zdawałoby się, naddatek?

Przypatrzmy się tym rozwiązaniom translatorskim, pozornie odbiegającym od oryginału. Summer frock - także w przekładach Mikosia i Czerniawskiego - jest słownikowym, wiernym przekładem słowa „letniczek”, lecz pozbawia je emocjonalnego sensu. Heaney proponuje frazę nacechowaną, a do tego misterniejszą, bo aliterowaną: flowered frock. Czy aliteracja zastapi sufiks spieszczający? Twierdzę, że zastąpi. Nie dzieje się to automatycznie, aliteracja nie ma przypisanego jej sensu spieszczającego, ale wydaje mi się, że w tym akurat przypadku wprowadza ona emocjonalne nacechowanie - bo bardziej nacechowana jest fraza zorganizowana i uporządkowana brzmieniowo, która - by powstać - wymagała od poety większego wysiłku niż summer frock. Kunsztowność angielskiej frazy zbliża ją, przynajmniej odrobinkę, do emocjonalnego nacechowania jej pierwotnej, polskojęzycznej postaci. Być może też należałoby uznać, że flowered frock jako określenie konkretniejsze, opisujące wygląd fartuszka - jego żywy, kolorowy i radosny wzór jest tym samym bliższe emocjonalnemu sensowi słowa z oryginału? Bo summer frock to tylko tyle, co fartuszek noszony latem.

Podobną próbę zbliżenia emocjonalnego między otwarcie uczuciową polszczyzną a relatywnie chłodną angielszczyzną znajdziemy u Heaneya $\mathrm{w}$ jego propozycji oddania rzeczownika „uploteczek" wyrażeniem złożonym: smootb ribbons. Polscy tłumacze, zarówno Mikoś, jak i Czerniawski, rezygnują z przywołania jakiegokolwiek echa oryginalnego spieszczenia; piszą najzwyczajniej: ribbon (wstążka). Czy nazwanie wstążek do włosów „wstążkami gładkimi/ delikatnymi”, można uznać za dążenie do zachowania ekwiwalencji emocjonalnej? Uważam, że tak. Nie mamy tu fonicznej kunsztowności aliterowanego flowered frock, ale wydobyta $\mathrm{w}$ angielskim przekładzie cecha, smoothness (gładkość), wywołuje dodatkowe, pozytywne skojarzenia.

W obu wypadkach pozornie opisowy, neutralny przymiotnik, zastosowany w omawianym przekładzie można potraktować jako próbę oddania sensu polskiego deminutywu, sensu nie semantycznego, ale emocjonalnego. W alternatywnych rozwiązaniach, jakie dali nam thumacze: summer dress (letnia sukienka) lub flowered dress (sukienka w kwiaty), ribbon (wstążka) lub smooth ribbon (gładka wstążka), wyrażenie drugie, choć formalnie niebędące spieszczeniami, jest wyraźnie cieplejsze.

Ciekawym przykładem opisywanego zagadnienia jest thumaczenie słowa „członeczki” $\mathrm{z}$ tego samego trenu. Obaj polscy thumacze rozwiązują problem deminutywu standardową przydawką: Czerniawski - tiny limbs, Mikoś - small limbs. To drugie 
rozwiązanie jest ewidentnie uboższe, pozbawione emocjonalności. Tiny limbs, dzięki fortunniej dobranemu przymiotnikowi, intensyfikuje małość, przemycając jednocześnie w przekładzie konstytutywną dla tego wiersza czułość.

U Heaneya tymczasem mamy bardzo swobodną transformację: Her body's warmth (ciepło jej ciała) - Heaney porzuca oryginalny rzeczownik „członeczki” i zastępuje go innym - oznaczającym ciepło, ich ciepło. Emocjonalna konotacja limbs (członków ciała) jest bez porównania uboższa niż konotacja warmth, ciepła, wartościowanego zawsze dodatnio, także jako cecha ludzkiego charakteru, a nie tylko jako zjawisko termiczne.

Wydaje mi się to, jeśli nie zamierzonym, niemniej konsekwentnie stosowanym przez Heaneya zabiegiem ekwiwalencji emocjonalnej - przybliżonej oczywiście, niepełnej, bardzo swobodnej, ale zapewne zmierzającej do oddania emocjonalności sensów $\mathrm{w}$ polszczyźnie. $\mathrm{W}$ innych trenach przełożonych przez Heaneya odnalazłem ślady podobnych zabiegów. Weźmy Tren III i dwa spieszczenia: „stopeczki” i „ręczynki”. Czerniawski tu znowu kapituluje - mamy więc u niego steps i embrace, wyrażenia całkiem neutralne, pozbawione pierwiastka emocjonalnego. Mikoś wybiera wariant podręcznikowy - dodaje przymiotniki oznaczające małość: little footsteps i tiny arms. Heaney natomiast używa wyrażeń wzbogaconych o sensy, których nie znajdziemy $\mathrm{w}$ oryginale: light foot (lekkie stopy) i slender arms (smukłe ramiona). Emocjonalny stosunek do stóp i dłoni dwuletniej dziewczynki wyraża Heaney nie sztampowym little, small, tiny, ale przymiotnikami, które świadczą o czułej uwadze, jaką te części ciała małej dziewczynki darzy jej ojciec. Większa konkretność, a także wypunktowanie cech wzbudzających radość oraz przyjemność, dowodzą silniejszego emocjonalnego zaangażowania podmiotu niż wypowiedź ogólna lub zwracająca uwagę tylko na rozmiar opisywanych części ciała.

Powróćmy więc do pytania: czy tłumaczący tekst na angielski jest skazany na nieczułość? Okazuje się, że niekoniecznie. Czułość, jak widzieliśmy, można wyrażać orkiestracją wiersza. Wprowadzane przez Heaneya aliteracje uznajmy za zabieg takiej nadorganizacji, która konotuje pozytywne nastawienie emocjonalne. Podobną funkcję, oddania w tekście czułości, pełnią stosowane przez Heaneya przydawki. Bo nie względy metryczne kazały Heaneyowi uzupełniać tekst epitetami waloryzowanymi dodatnio, a z pewnością nie miał tu także znaczenia wątpliwy imperatyw wierności wobec oryginału. Tym, co kazało tak postąpić tłumaczowi, była próba oddania czułości, kategorii całkiem pozatranslatologicznej, czy wręcz pozasystemowej. 
Spójrzmy teraz, co się dzieje, kiedy z języka pozbawionego zdrobnień przekładamy na język w zdrobnienia obfitujący. Za materiał ilustracyjny posłuży nam powieść Ronalda Firbanka The Flower Beneath the Foot ${ }^{\mathrm{I}} \mathrm{i}$ jej przekład autorstwa Andrzeja Sosnowskiego, Zdeptany kwiatuszek ${ }^{\text {II }}$. Nie bez kozery zestawiam właśnie te dwa teksty: po pierwsze, przekład Sosnowskiego jest nasycony zdrobnieniami i spieszczeniami; po drugie, na pewno nie są one przeniesieniem kilku deminutywów występujących $\mathrm{w}$ angielskojęzycznym oryginale; po trzecie, konotowana przez nie czułość i pieszczotliwość ma inne niż w przypadku Kochanowskiego znaczenie.

W Zdeptanym kwiatuszku thumacz właściwie bez ograniczeń zdrabnia i spieszcza. Możemy postawić pytanie: czy tekst w jakikolwiek sposób go do tych zdrobnień prowadzi, czy też są one swoistym naddatkiem stylistycznym obcym oryginałowi, a związanym bardziej $\mathrm{z}$ indywidualnymi upodobaniami thumacza, tudzież z konwencjami obowiązującymi w języku docelowym?

Powieść Firbanka to fajerwerkowy popis estetyki kampu, święto sztuczności, teatralizacji i dystansu graniczącego z perwersją. Sosnowskiemu z kolei - poecie - estetyka kampu, której autor nadaje wyraźne rysy postmodernistycznej świadomości, jest szczególnie bliska, o czym pisała niedawno Inez Okulska ${ }^{\mathrm{I} 2}$. Co więcej, poezja Sosnowskiego obfituje w zdrobnienia i spieszczenia. Na to, że jego poezja uwodzi, zwracali uwagę różni krytycy, na przykład Anna Kałuża podczas debaty poświęconej językom miłości we współczesnym wierszu, która odbyła się podczas warszawskich Manifestacji Poetyckich we wrześniu 2011 r.: „Andrzeja Sosnowskiego nie nazwałabym poetą miłości, raczej poetą uwodzenia" ${ }^{\text {I3 }}$. A do tego celu zdrobnienia i spieszczenia doskonale się nadają: Sosnowski często robi z nich użytek, wykorzystując także deminutywa czysto formalne, które straciły sens zdrobnień, jak choćby w tytule tomu wierszy zebranych Pozytyweki i marienbadki. Emocjonalne ciepło wierszy Sosnowskiego podszyte jest jednak ironicznym dystansem, jakby czułość sama siebie brała w nawias, nie niwelowała się, ale uniemożliwiała jednoznaczne przyjęcie tego, co się w wierszu mówi, bo to, co się w tej poezji mówi, nie powinno podlegać prawdzi-

ro R. Firbank, Five Novels, New York 1981.

II R. Firbank, Zdeptany kwiatuszek, thum. A. Sosnowski, Warszawa 1998.

I2 I. Okulska, Miłość a fetysz a spotkanie języków. W zwiazku z Ronaldem Firbankiem, w: Wiersze na głos. Szkice o twórczości Andrzeja Sosnowskiego, red. P. Śliwiński, Poznań 2010, s.168-177.

I3 Miłość jest permanentna rewolucja - zapis debaty, „Wakat” 2011, nr 15 (wersja internetowa - http://www.sdk.pl/wakat/nr 15/dyskusja.html, dostęp: 4 maja 2014). 
wościowej weryfikacji, jest flirtem, grą estetyczną, a więc czymś, co wychodzi poza kategorie prawdy i fałszu, a nawet powagi i niepowagi.

Nic dziwnego, że poeta, który funduje swoją poetykę na tego typu zjawisku językowym, upodobał sobie zdrobnienia i spieszczenia również w swojej pracy przekładowej. Dla Okulskiej deminutywa, gęstsze w przekładzie Sosnowskiego niż w oryginale Firbanka, to „przeniesienie własnej poetyckiej inklinacji do infantylizacji języka" ${ }^{\text {4 }}$. Trudno się z tym rozpoznaniem nie zgodzić: twórczość translatorska jest tu wyraźnym przedłużeniem twórczości własnej.

Jak działają te deminutywa, widać już w przekładzie tytułu powieści Firbanka. Jej angielska wersja zatytułowana jest Flower Beneath the Foot, co można przetłumaczyć dosłownie i neutralnie (czyli bez zdrobnień) na „Kwiat pod stopą”. Ale to, zgodzimy się, żaden przekład. I żaden tytuł. Sosnowski tłumaczy ten tytuł pomysłowo i twórczo jako Zdeptany kwiatuszek. Neutralny kwiat staje się więc deminutywem drugiego stopnia, w szeregu: kwiat kwiatek - kwiatuszek. Nie sposób, nawet nie znając powieści, nie odczytać w jej polskim tytule tego zdrobnienia jako znaku innych jeszcze sensów niż deminutywny: chodzi nie tylko o kwiat, który jest mały. To nie jest small flower. Czy to zatem spieszczenie? A więc nacechowanie słowa czułością? Niby tak, ale to czułość zdecydowanie inna niż ta, którą widzieliśmy w Trenach. Czuję bowiem $\mathrm{w}$ polskim tytule angielskiej powieści, a mam nadzieję, że nie jestem w tym odczuciu odosobiony, ironię. Autor, czyli thumacz, gra z nami. To jest teatralny gest, nieco karykaturalny, podszyty zamiłowaniem do przesady. Ironiczny wydźwięk tytułu wzmacnia zastosowana tu przydawka: „zdeptany” - sugestia brutalności, bezwzględności i gwałtu kontrastuje z ewokowaną przez deminutyw kruchością kwiatuszka. Tak silnej ironii nie znajdziemy $\mathrm{w}$ angielskiej frazie, zdecydowanie spokojniejszej i opisowej. Tytuł polski staje się kluczem całego przekładu. Jako czytelnik nie dziwię się już bogactwu zdrobnień, jakie znajdziemy w powieści, bo zapowiedział je tytułowy „kwiatuszek”.

O ironicznym potencjale polskich deminutywów pisał Michał Sarnowski ${ }^{15}$. Zwracał uwagę, że znaczenie ironiczne mają deminutywa utworzone od rzeczowników wtórnie wartościujących dodatnio, na przykład anioł - aniołek, złoto - złotko. W tej kategorii mieści się oczywiście „kwiatuszek”. Dla odróżnienia,

${ }^{14}$ I. Okulska, op.cit., s. 172.

${ }_{5}$ M. Sarnowski, Deminutywum jako znak ironii, w: Jezzyk a kultura, t. 3: Wartości w języku i tekście, red. J. Puzynina, J. Anusiewicz, Wrocław 1991, s. $41-50$. 
deminutywa rzeczowników wartościujących ujemnie intensyfikują negatywną cechę lub ją neutralizują: bagno - bagienko, typ - typek ${ }^{16}$. Sarnowski przypomina zarazem, że ironiczny wydźwięk nie jest zasługą samych deminutywów, ale kontekstu lub sytuacji komunikacyjnej. Ironiczne deminutywa są według badacza „przypadkami zamierzonej nieszczerości”, świadectwem „fałszywego ugrzecznienia”, widocznego choćby w stosowanych często deminutywnych zwrotach: „paniusia”, „panienka” ${ }^{17}$.

Ceremonialność kampowego świata Firbanka, teatralność gestów, grzeczność wystylizowana, podszyta perwersją lub złośliwością, dopraszały się wprowadzenia do przekładu zdrobnień, nawet tam, gdzie oryginał angielski zdrobnień bynajmniej nie zaznacza. Jeśli Sosnowski tłumaczy, że ktoś poprawiał „czuprynkę", choć u Firbanka mamy short shock of hair, albo pisze o ,poufnej pogaduszce”, gdy w oryginale jest intimate chat, albo o „kołderkach”, gdy mamy comforts, czy też o „młodziutkim paziu", gdy w oryginale jest youthful page - to dlatego, że charakter tej narracji jest wyraźnie ironiczny, a ironię w polszczyźnie zaznaczyć można właśnie zdrobnieniami. Skoro polszczyzna może wykorzystywać deminutywa jako znaki ironii, tłumacz czuje się uprawniony do takiego zabiegu. I na potęgę zdrabnia. Spójrzmy na kilka przykładów z początku powieści, w których formy te obejmują nie tylko rzeczowniki, ale też przymiotniki i przysłówki, tworząc tekst naznaczony jednocześnie czułością i ironią:

Podciągnij haleczkę, markizo

(Pull up your skit, marquise)

młoda osóbka

(the young creature)

Murzynka z margaretką smaży się na słoneczku/ Myśli o cacuszkach widocznych pod haleczką

(A negress with a Margaret once lolled frousting in the Sun/ Thinking of all the little things that she had left undone)

Kiedy powolutku ruszyli dalej

(As they sauntered on)

miniaturowe jeziorko

(miniature lake)

\footnotetext{
${ }^{16}$ Ibidem, s. 42.

${ }^{7}$ Ibidem, s. 44-46.
} 
Bądź milutki

(Be sweet)

W jednokonnej bryczuszce

(In a Little one-horse shay)

Czego mi zatem trzeba, to angielskiej pokojóweczki

(What I want is an English maid)

Spotkanko?

(Is it a party?).

Czasem ironia zaznacza się w wyrazie, który pod względem rejestru jest przeciwieństwem słowa użytego w oryginale, jakby w potwierdzeniu o przyciąganiu się przeciwieństw. U Firbanka mamy na przykład abdomen, słowo techniczne, z lekka pretensjonalne, obce, a z pewnością ironicznie użyte w kontekście jego narracji, Sosnowski tymczasem wybiera słowo z przeciwległego bieguna: „brzuszek”, uzyskując przez zastosowanie nieobecnej w oryginale deminutywności podobny efekt - ironii.

Kampowość stylu Firbanka można by oddać na wiele sposobów: szykiem zdania, neologizmami, wyrafinowanym słownictwem, przestylizowaną frazelogią. Sosnowski wybiera przede wszystkim spieszczenia, z pewnością ze względu na swoje upodobanie do tego, co Okulska nazwała „,infantylizacją języka"; nie jest to jednak przekłamanie oryginału, ani też arbitralne narzucanie na oryginał własnych upodobań stylistycznych. Te własne upodobania Sosnowskiego w przekładzie oczywiście są, ale wpisują się one w stylistykę oryginału. Autorski charakter użytych spieszczeń, czyli silne wrażenie, że są one naddatkiem Sosnowskiego, bierze się stąd, że podobnych form w angielszczyźnie Firbanka prawie nie uświadczymy. Nie ulega kwestii, że są one celnym ekwiwalentem Firbankowskiej ironiczności, wyrażeniem tych samych treści za pomocą środków swoistych dla polszczyzny. Thumacz Zdeptanego kwiatuszka mógł sobie pozwolić na czułość mistrzowsko wprzęgniętą w służbę kampowej ironii.

Powróćmy na koniec do ogólniejszych pytań. Czy ekwiwalencja emocjonalna jest konieczna, a jeśli tak, to czy jest możliwa? Jeśli tłumaczymy z języka pełnego zdrobnień na język tych zdrobnień praktycznie pozbawiony, czy w języku docelowym przekładu powinniśmy szukać za wszelką cenę ekwiwalentów tychże zdrobnień? Czy musimy - czy możemy - być w angielszczyźnie równie czuli, jak w języku polskim? A może: czuli inaczej? Przecież względny brak zdrobnień charakteryzuje język angiel- 
ski, to jeden z jego wyróżników, takich jak choćby nieobecność fleksji czy present perfect.

Spieszczanie w przekładzie na angielski, zarówno za pomocą przyrostków, jak i w sposób opisowy, wszędzie tam, gdzie mamy do czynienia z polskim deminutywem, może być narzucaniem angielszczyźnie obcej jej cechy. To trochę tak, jakby polski tłumacz, przekładając $\mathrm{z}$ angielskiego, próbował zachować $\mathrm{w}$ polszczyźnie wszystkie przypadki strony biernej, jakie występują w wersji pierwotnej, zapominając, że język polski nie jest wobec niej tak tolerancyjny. Ale podobnym zabiegiem - działaniem wbrew osobliwości języka oryginału - byłoby thumaczenie na polski, które unikałoby spieszczeń z racji tego, że formalnie nie występują one w angielskojęzycznym tekście wyjściowym. Odrębność językowa jest wartością, a próby ujednolicenia języków budzą poważne wątpliwości. W kulturze angielskiej czułość wyrażana jest innymi środkami i mniej otwarcie niż w polskiej kulturze. Angielski pozwala uczucia okazywać przez przywołanie szczegółów lub cech danej rzeczy, bo uwaga dla Anglika może być wystarczającym znakiem czułości. Czułość w tekście angielskim bywa też niekiedy wpisana w misterną formę wiersza, w jego uporządkowanie brzmieniowe i rytmiczne. Tymczasem spieszczenia w polszczyźnie mogą być artystycznie skutecznym znakiem ironii - toteż unikanie ich $\mathrm{w}$ polskim przekładzie tylko dlatego, że nie ma ich w tekście angielskim, byłoby błędem. System spieszczeń w polszczyźnie to jej swoista cecha. To także pożyteczny mechanizm, za pomocą którego wyraża ona treści zawarte w tekstach obcojęzycznych pod innymi postaciami. Istnieją bowiem różne języki czułości, a tłumacz, pamiętając o tym, nie tylko może, ale i musi pozwolić sobie na czułość.

\section{JERZY JARNIEWICZ}

\section{Can a translator afford affection? Hypocorism and emotional equivalence in literary translation}

One of the most frequent problems in translation is the question of translation of hypocorisms: inasmuch as Polish is rich in diminutives, English practically does not have them. Diminutive and affectionate forms in a very limited range of contexts, and descriptive (analytical) diminutives are of little stylistic interest.

The article discusses examples of coping with this problem in translations both from Polish into English, and from English into Polish. The authors tries to answer the question if it is possible to retain the emotionality expressed in diminutives of a translated text. Two texts 
were selected for the analysis: Jan Kochanowski's Laments in Stanisław Barańczak and Seamus Heaney's translation, and Ronal Fairbank's The Flower Beneath the Foot, translated by Andrzej Sosnowski. Laments, addressed to a dead child, are of particular interest for the analysis, because diminutives and terms of endearment are frequently used and perform a peculiar function of creation of meaning. Discussing this translation, the author of the article tries to demonstrate that the emotionality expressed by Kochanowski through hypocorisms has been expressed by other means in the English translation: the right choice of epithets, and orchestration of the verse. In the Polish translation of Firbank's novel, the hypocorisms introduced by the translator are read not as an arbitrary addition, but as elements that contribute to the camp climate of the novel, and reflect the irony, artificiality, and theatricality of the work, by means that are accessible in Polish language.

Keywords: literary translation, diminutive and hypocorism in translation, equivalence.

Jerzy Jarniewicz - tłumacz, poeta, krytyk literacki, profesor UŁ. Redaktor „Literatury na Świecie”. Autor dziewięciu książek krytycznoliterackich, między innymi Heaney. Wiersze pod dotyk (2011) oraz Gościnność stowa. Szkice o przektadzie literackim (2012). Wśród przełożonych przez niego utworów znalazły się dzieła Jamesa Joyce'a, Philipa Rotha, Edmunda White'a, Johna Banville'a, Raymonda Carvera oraz antologia Sześć poetek irlandzkich (2012). 